\title{
Propozycja synergicznego zarządzania i oszczędzania energii w osiedlu mieszkaniowym opartej na opinii mieszkańców - przykład Lublina
}

\author{
Anna Ostańska \\ https://orcid.org/0000-0002-1789-4288 \\ a.ostanska@pollub.pl
}

Katedra Architektury, Urbanistyki i Planowania Przestrzennego,

Wydziat Budownictwa i Architektury, Politechnika Lubelska

\begin{abstract}
Streszczenie: W ramach propozycji synergicznego zarządzania osiedlem mieszkaniowym poddano analizie, zebrane w wywiadzie bezpośrednim, wieloaspektowe opinie wyrażone przez samych użytkowników eksploatowanych od lat wielorodzinnych budynków. Wynikiem analiz było określenie najczęściej popieranych przez mieszkańców aspektów i wskazanie dalszych kierunków możliwych i akceptowanych działań. Następnie dokonano wyboru najpilniejszych działań wskazanych przez mieszkańców pod względem oszczędzania energii, które zsynchronizowane możliwościami finansowych zarządcy, mogą przyczynić się do spójnego projektowania przyszłych działań naprawczych i bezkolizyjnej realizacji.
\end{abstract}

Słowa kluczowe: lokal mieszkalny, budynek wielorodzinny w eksploatacji, osiedle mieszkaniowe, oszczędzanie energii, opinia użytkowników

\section{Wstęp}

W ostatnim czasie, ze względu na regularny wzrost opłat za energię cieplną, zauważono zwiększone zainteresowanie mieszkańców budynków wielorodzinnych w aspekcie wykorzystania możliwych oszczędności i zmniejszenia kosztów ich utrzymania. Tendencję taką potwierdziły również przeprowadzone i opisane w artykule autorskie ankiety. Jednocześnie zbadano chęć pozostania na osiedlu oraz różne braki wynikające z wieku budynków, ich wyposażenia technicznego i aktualnego wieku oraz wymagań użytkowników. To skłoniło do wniosku, że podejście winno być synergiczne zarówno do prowadzonych, jak i planowanych jeszcze działań naprawczych, w tym termomodernizacji. Synchronizacji działań wymagają także funkcjonalność poszczególnych lokali mieszkalnych, jak i budynki oraz całe osiedla. Na tej podstawie stwierdzono, że tylko odpowiednia ocena zasadności proponowanych rozwiązań oszczędzających energię i wskazanie możliwej dalszej ścieżki działań umożliwi synergiczne planowanie strategicznych działań. Do tego przydatne wydaje się być wielodyscyplinarne podejście do badań na przeprowadzenie analizy aktualnych problemów występujących w danym obszarze jednostki urbanistycznej i interakcji pomiędzy mieszkańcami/użytkownikami a zarządca.

W artykule przeprowadzono analizę w wybranych aspektach eksploatowanych od 40 lat zasobów budownictwa wielorodzinnego, co pokazano w warunkach polskich na przykładzie Lublina. Przyjęta metoda badawcza charakteryzuje się kompleksowym podejściem zmierzającym do właściwej, oceny parametrów funkcjonalnych i energetycznych. 


\section{Dane statystyczne - wybrane wskaźniki}

W ramach przeprowadzanych, na przykładzie Lublina, badań wstępnych dokonano ogólnej analizy charakterystyki wybranego obszaru badawczego. W tym celu zestawiono wybrane wskaźniki usług miejskich i jakości życia zgodne z metodologią PN-ISO 37120:2015 [1] ' co pokazano w tabelach 1-2. Z dokonanego zestawienia (Tab. 1) wynika, że w roku 2016 największą grupę mieszkańców Lublina stanowią osoby w wieku 25-64 lat.

Tabela 1. Wybrane wskaźniki profilowe dla miasta Lublina

\begin{tabular}{|c|c|c|c|}
\hline Lp. & Wskaźnik profilowy & Wartość & Rok \\
\hline 1. & Całkowita populacja miasta & 340466 & 2016 \\
\hline 2. & Odsetek osób, które są dziećmi (0-14 lat) & $14,02 \%$ & 2016 \\
\hline 3. & Odsetek osób, które są młodzieżą (15-24 lat) & $9,04 \%$ & 2016 \\
\hline 4. & Odsetek osób, które są dorosłymi (25-64 lat) & $58,65 \%$ & 2016 \\
\hline 5. & Odsetek osób, które są seniorami (65+ lat) & $18,29 \%$ & 2016 \\
\hline 6. & Łączna liczba gospodarstw domowych & 144444 & 2011 \\
\hline 7. & Liczba zajmowanych jednostek mieszkalnych & 149506 & 2016 \\
\hline
\end{tabular}

Charakterystyczne dane wskaźników profilowych przedstawia zużycie energii w mieście, które w roku 2016 wynosiło prawie $690 \mathrm{kWh} /$ rok, przy czym energia odnawialna stanowiła niewiele ponad 0,01\% w skali całego zużycia. Wyniki analizy statystycznej potwierdzają, że w kwestii stosowania OZE w mieście Lublin jest jeszcze dużo do zrobienia.

Tabela 2. Wybrane elementy zestawienia wskaźników energii w Lublinie rok 2016

\begin{tabular}{|c|c|c|c|}
\hline Lp. & Wskaźnik profilowy & Wartość & Rok \\
\hline 1. & $\begin{array}{l}\text { Całkowite zużycie energii elektrycznej } \\
\text { w gospodarstwie domowym na mieszkańca }\end{array}$ & $687,5 \mathrm{kWh} / \mathrm{rok}$ & 2016 \\
\hline 2. & $\begin{array}{l}\text { Odsetek mieszkańców miasta objętych } \\
\text { legalną dostawą energii elektrycznej }\end{array}$ & $99,98 \%$ & 2016 \\
\hline 3. & Zużycie energii przez budynki publiczne na rok & $86,39 \mathrm{kWh} / \mathrm{m}^{2}$ & 2016 \\
\hline 4. & $\begin{array}{l}\text { Odsetek całkowitej energii uzyskanej ze źródeł odnawialnych, } \\
\text { jako część całkowitego miejskiego zużycia energii }\end{array}$ & $0,013 \%$ & 2016 \\
\hline 5. & Całkowite zużycie energii na mieszkańca & 2792 kWh/rok & 2016 \\
\hline
\end{tabular}

Tym bardziej istotnym wydaje się być aktualne dane powierzchniowe i demograficzne oraz określenie tendencji wzrostu demograficznego. Na podstawi e dalszych analiz stwierdzono, że w roku 2019 powierzchnia terenu miasta Lublin zajmowała 148 km². A liczba ludności wynosiła 339.784 osób, w tym (Ryc. 1): 183075 kobiet (54\%) i 156709 mężczyzn (46\%). 


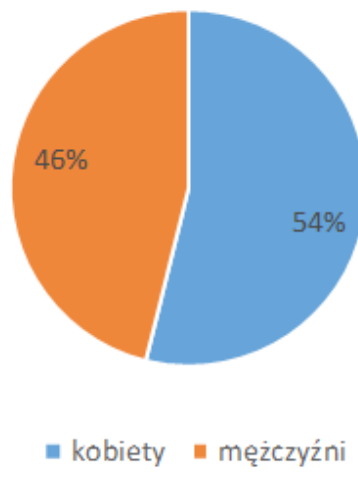

Ryc. 1. Liczba ludności m. Lublina, to 339.784 osób, w roku 2019 a wykres podano wg podziału płci

Analizie poddano też strukturę demograficzną [1] mieszkańców miasta Lublin, w której największą grupę (blisko 50\% spośród trzech) stanowią osoby w wieku poprodukcyjnym. Z kolei szczegółowa analiza tendencji wzrostu lub spadku liczby osób w każdej z grup wiekowych, pod względem ekonomicznym, przedstawia się następująco: liczba osób, w roku 2019 w stosunku do roku 2015, w wieku przedprodukcyjnym była większa o 0,7\%, w wieku produkcyjnym mniejsza o 2,9\%, a w wieku poprodukcyjnym większa o 2,2\%. Zatem najbardziej zmniejszyła się grupa osób w wieku produkcyjnym a wzrosła grupa osób w wieku poprodukcyjnym.

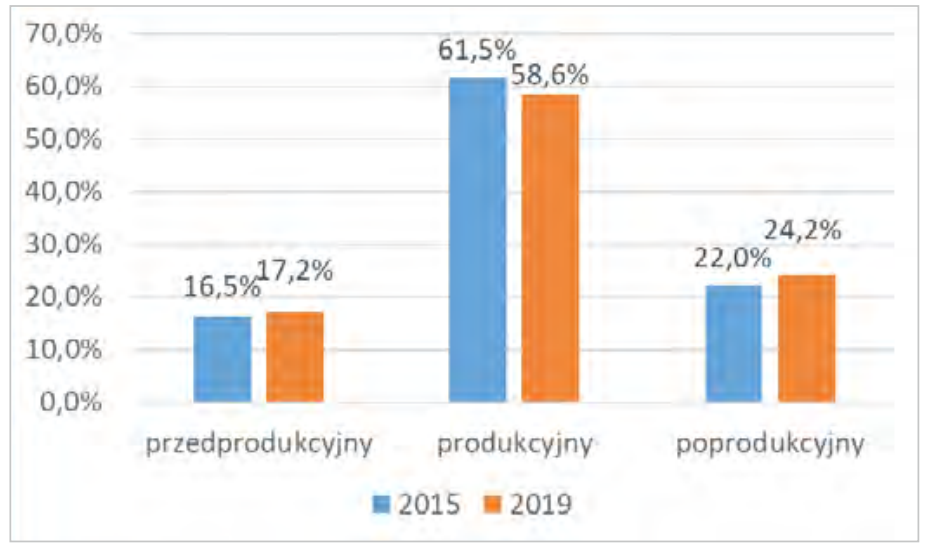

Ryc. 2. Ludność miasta Lublin wg ekonomicznych grup wieku

Istotnym dla zarządców wydaje się być także fakt dostępnej prognozy demograficznej i to zarówno na rok 2020 (Ryc. 3), jak i na 2050 (Ryc. 4), który potwierdza tendencje z wcześniej omówionych lat(lata 2015 i 2019). Zatem w następnych latach nastąpi dalszy spadek liczby osób w wieku produkcyjnym a wzrost liczby mieszkańców w wieku poprodukcyjnym. To jest już dziś ważny sygnał dla zarządców w Lublinie, w jakim kierunku powinni planować dalsze działania poprawy eksploatowanej budynków, bowiem malejące możliwości ekonomiczne użytkowników wynikają z powiększenia grupy osób w wieku poprodukcyjnym, czyli będących na utrzymaniu państwa i mniej zaradnych finansowo. Niewątpliwie należy uwzględnić potrzeby starzejącego się mieszkańca, ze szczególnym uwzględnieniem konieczności poprawy funkcjonalnej i zmniejszenia zużycia kosztów utrzymania lokali mieszkalnych a tym samym całych budynków.

I choć panująca od 2020 roku pandemia znacząco zweryfikowała grupę osób poprodukcyjnych, to nadal nie ma wiarygodnych danych aby można byłoby stwierdzić możliwość odwrócenia tendencji do starzenia się społeczeństwa a konkretnie, w analizowanym przypadku, mieszkańców Lublina. Tym samym zachodzi konieczność synergicznego rozpoznania problemów i myślenia, już dziś, o możliwym usprawnieniu funkcjonalności mieszkań, dostępności budynków i całych obszarów i poprawy energetycznej budynków oraz większego ukierunkowania jej na OZE. 


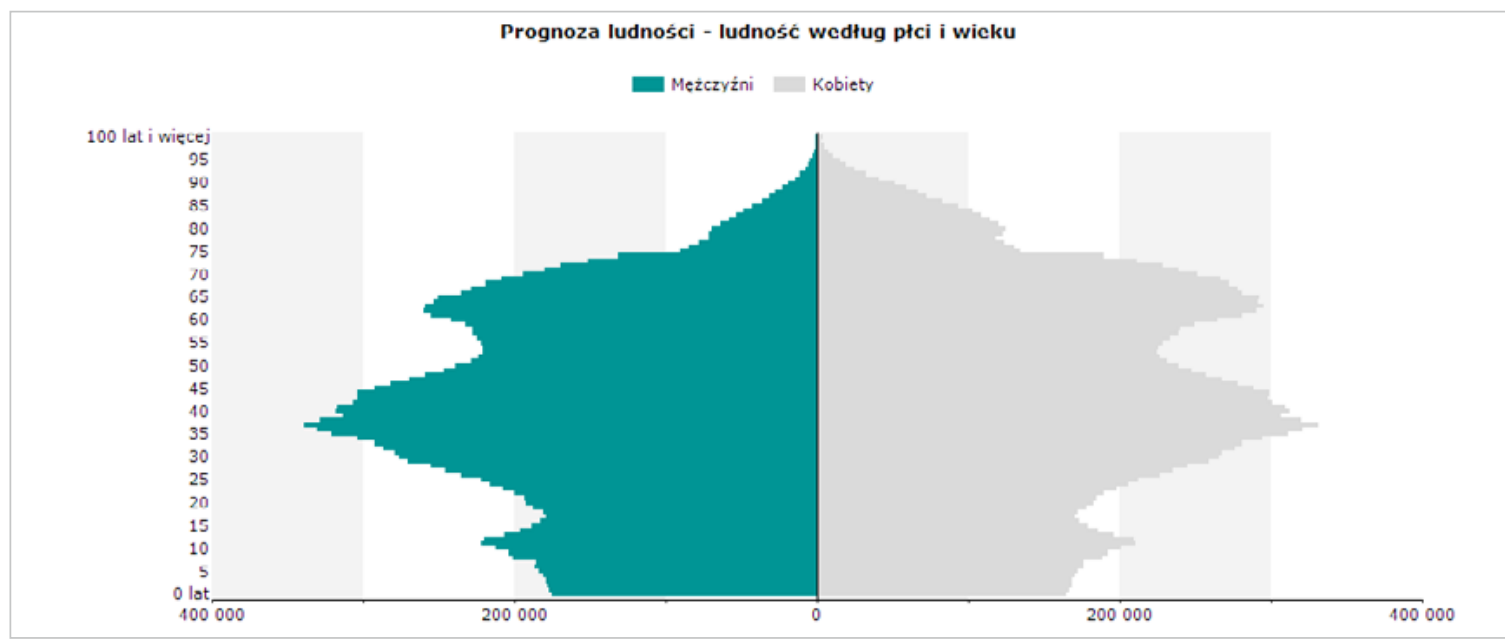

Ryc. 3. Prognoza ludności wg płci i wieku na rok 2020 [2]

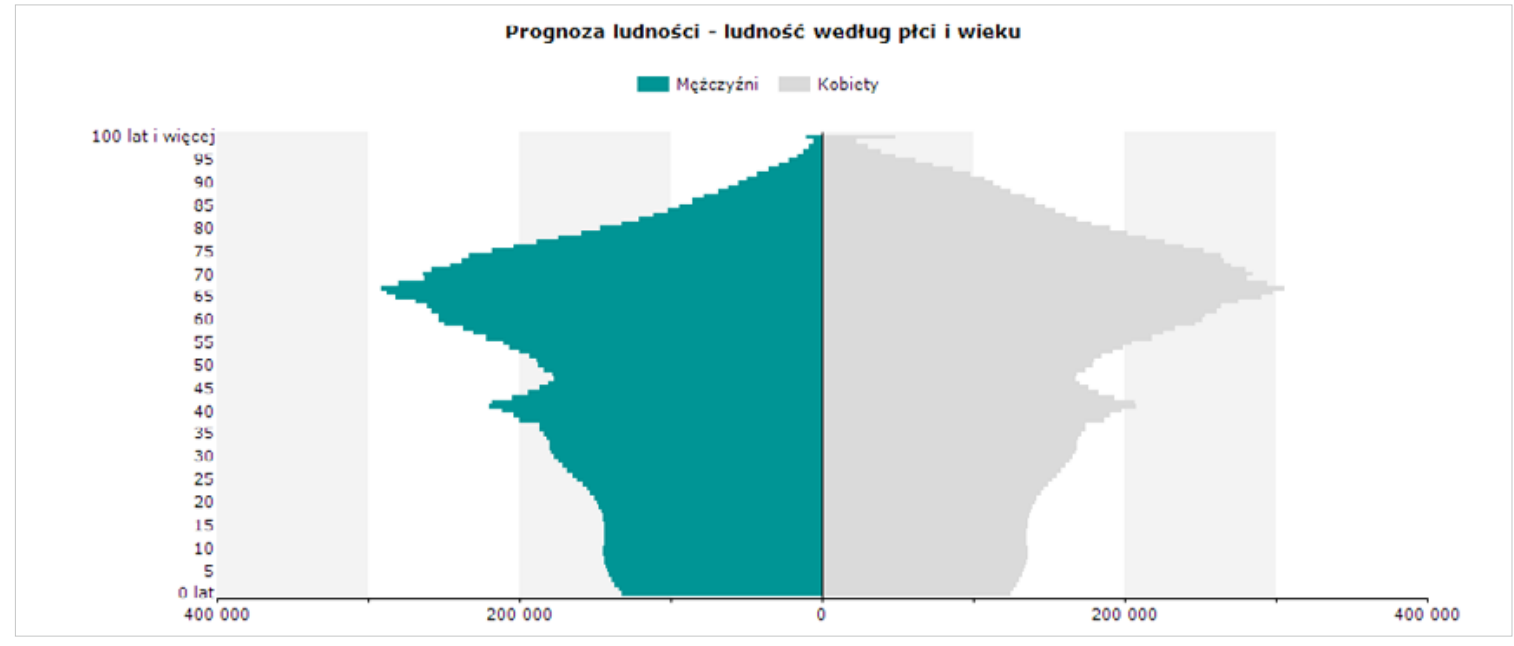

Ryc. 4. Prognoza ludności wg płci i wieku na rok 2050 [2]

\section{Metodologia}

Badania oparto na wzorcach ankiet socjologicznych [1] wzbogaconych o metody i techniki wynikające z doświadczeń społecznych omówionych przez Sztumskiego [7] oraz pierwsze opracowania własne [5] i kilkunastoletnie doświadczenia autorki [6]. Ankiety środowiskowe wypełniano w pogłębionym wywiadzie bezpośrednim. Opracowany formularz zawierał 19 pytań, pytano też o płeć. Pytania dotyczyły w szczególności: opinii o problemach osiedla i oczekiwaniach mieszkańców, struktury społecznej osiedla i ewentualnej partycypacji mieszkańców w rewitalizacji służącej poprawie funkcjonalnej wraz z uzupełnieniem informacji o pracach wykonanych w mieszkaniach oraz oszczędności energii.

Wytypowano mieszkańców w wieku od 18 do 80 lat. Wyselekcjonowano spośród nich cztery grupy wiekowe: 18-25 lat, 26-45 lat, 46-65 lat i powyżej 65 lat. Przykładowo w jednym z osiedli ankiecie poddano 245 osób spośród 1557 mieszkań, ponieważ z każdego mieszkania badano jedną osobę. Liczba ankiet stanowi zatem reprezentatywną próbę (ponad 15\% mieszkań) dla dalszych analiz. Pytania pozwoliły na uzyskanie informacji odnoszących się do:

- płci i wieku poddanych badaniom mieszkańców Lublina (Ryc. 5),

- braków w przestrzeni osiedli z budynkami prefabrykowanymi i partycypacji społecznej (Tab. 4), 
- zadowolenia mieszkańców z rozkładu funkcjonalnego pomieszczeń (Tab. 5),

- przyczyn migracji z budynku (Tab. 6),

- propozycji poprawy estetyki i wyposażenia budynków (Tab. 7),

- propozycji poprawy wyposażenia mieszkań (Tab. 8),

- propozycji uzupełnienia wyposażenia w sąsiedztwie budynku (Tab. 9),

- propozycji zmniejszenia zużycia energii cieplnej w budynku (Tab. 10),

- pilnych prac naprawczych i deklarowanej partycypacji finansowej (Tab. 11).

\section{Ocena możliwości zastosowania synergicznego systemu zarządzania ukierunkowanego na zwiększenie funkcjonalności mieszkań i efektywności energetycznej budynku}

Elementem przyjętej metodologii jest wyznaczenie kierunków dla oceny energetycznej lokali mieszkalnych, budynków i osiedla. Polega ono na analizie materiałów analitycznych z podziałem na: liczbę mieszkań i zebranie ocen (metodą PAPI) wyrażonych przez mieszkańców aktualnych potrzeb dotyczących, m.in. komfortu zamieszkania czy jakości energetycznej budynków w aktualnym stanie zaawansowania procesu termomodernizacji analizowanego obszaru, np. w dzielnicy czy osiedlu.

Ocenę możliwości szerszego oddziaływania zastosowanego synergicznego systemu zarządzania ukierunkowanego na zwiększenie funkcjonalności mieszkań i efektywności energetycznej budynku rozpoczęto od określenia struktury społecznej obszaru badawczego. W tym celu zbadano zabudowę wybranych obszarów, w których scharakteryzowano średnią liczbę eksploatowanych lokali w stosunku do liczby mieszkańców w określonych przedziałach (Tab. 3).

Tabela 3. Zestawienie liczby lokali mieszkalnych w badanych budynkach eksploatowanych w poszczególnych strefach energetycznych, wg kryterium liczby mieszkańców ${ }^{2}$

\begin{tabular}{|c|c|cc|}
$\begin{array}{c}\text { Liczba } \\
\text { mieszkańców } \\
\text { [szt.] }\end{array}$ & $\begin{array}{c}\text { Strefa czerwona } \\
\text { Ogrzewanie węglem } \\
\text { Liczba lokali [szt.] }\end{array}$ & $\begin{array}{c}\text { Strefa żółta } \\
\text { Ogrzewanie z sieci miejskiej } \\
\text { Liczba lokali [szt.] }\end{array}$ & $\begin{array}{c}\text { Strefa zielona } \\
\text { Ogrzewanie gazem } \\
\text { Liczba lokali [szt.] }\end{array}$ \\
\hline $\mathbf{0 - 2 0}$ & $7+8+8+2+1+1=27$ & 1 & $3+1=4$ \\
\hline $\mathbf{2 0 - 5 0}$ osób & 0 & $20+19+14+23+22=98$ & 0 \\
\hline $\begin{array}{c}\mathbf{5 0 - 1 0 0} \\
\text { osób }\end{array}$ & 33 & $32+46+57+51+37+29+$ & 0 \\
\hline $\begin{array}{c}\text { Powyżej } \\
\mathbf{1 0 0} \text { osób }\end{array}$ & 40 & $50=272$ & 103 \\
\hline
\end{tabular}

\section{Wyniki i analiza badań}

Przeprowadzona analiza oparta została na kryterium wieku mieszkańców, co dało orientację z jaką grupą osób mamy do czynienia w przypadku podejmowania rozmów w sprawie polepszenia jakości życia. Z analizy statystycznej wynika, że największą grupę stanowią mieszkańcy w wieku od $46 \div 65$ lat i to zarówno kobiety, jak i mężczyźni (ponad 20\%, Ryc. 5), co daje w sumie $45 \%$ badanej populacji. 


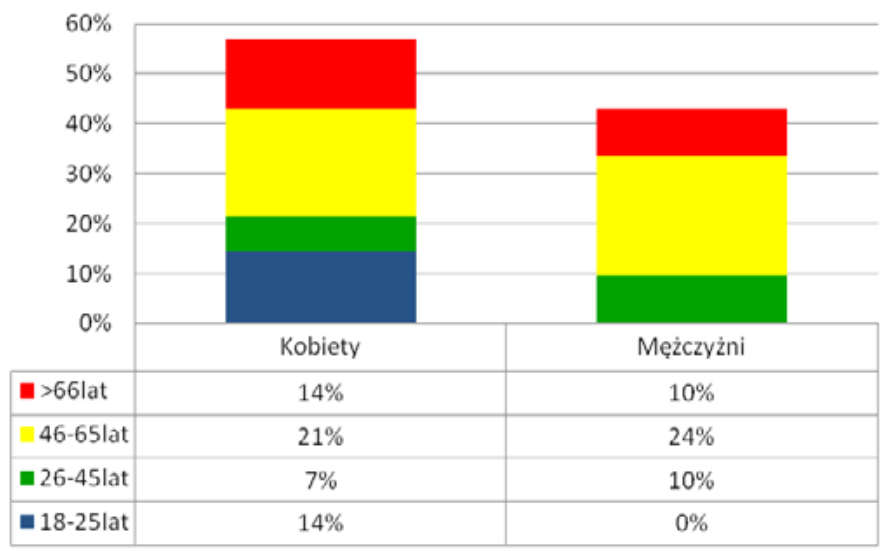

Ryc. 5. Płeć i wiek poddanych badaniom mieszkańców Lublina, listopad-grudzień 2010

Następnie przeprowadzono analizę wybranych do badań obiektów towarzyszących i infrastruktury na badanym obszarze. W tab. 4 przedstawiono opinię mieszkańców na temat braków w wyposażeniu analizowanego osiedla i jego infrastruktury wg kryterium wieku.

W ocenie zagospodarowania przestrzeni osiedla mieszkańcy wskazują na brak dostatecznej ilości ławek (84\%) i koszy na śmieci (68\%). Mieszkańcom brakuje też miejsc parkingowych (67\%), parku linowego (62\%) i niewiele mniej: dobrego utrzymania zieleni i konieczność zmodernizowania placów zabaw (60\%); są to osoby głównie w wieku 46-65 lat.

Równocześnie ponad połowa mieszkańców (52\%) nie wyraża chęci udziału w pracy społecznej na rzecz poprawy stanu zagospodarowania osiedla, głównie osoby w wieku od 26 do 65 lat, czyli dwóch kategorii wiekowych.

Tabela 4. Zestawienie braków w przestrzeni osiedli z budynkami prefabrykowanymi i partycypacji społecznej w opinii mieszkańców Lublina, wg kryterium wieku

\begin{tabular}{|c|c|c|c|c|c|c|c|c|c|c|c|c|c|c|c|}
\hline$\stackrel{\text { 임 }}{3}$ & 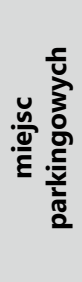 & 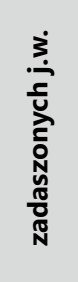 & 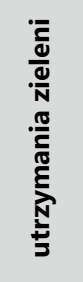 & 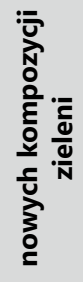 & 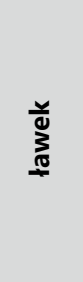 & 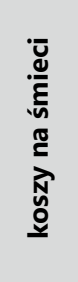 & 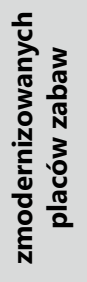 & 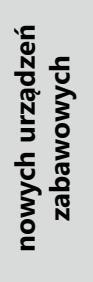 & 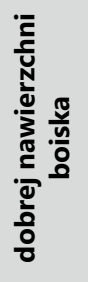 & $\begin{array}{l}\bar{z} \\
\frac{2}{\pi} \\
\frac{0}{9} \\
\frac{\pi}{\pi} \\
\frac{2}{4}\end{array}$ & 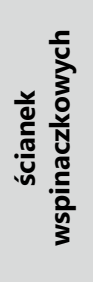 & 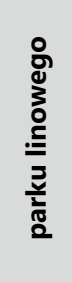 & 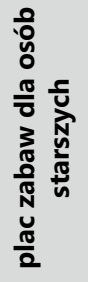 & 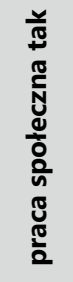 & 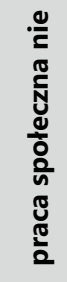 \\
\hline 18-25 lat & $10 \%$ & $2 \%$ & $5 \%$ & $2 \%$ & $9 \%$ & $9 \%$ & $5 \%$ & $7 \%$ & $5 \%$ & $7 \%$ & $7 \%$ & $7 \%$ & $7 \%$ & $5 \%$ & $5 \%$ \\
\hline 26-45 lat & $10 \%$ & $5 \%$ & $12 \%$ & $12 \%$ & $14 \%$ & $16 \%$ & $12 \%$ & $5 \%$ & $2 \%$ & $14 \%$ & $14 \%$ & $14 \%$ & $12 \%$ & $14 \%$ & $2 \%$ \\
\hline 46-65 lat & $33 \%$ & $21 \%$ & $31 \%$ & $26 \%$ & $40 \%$ & $36 \%$ & $31 \%$ & $33 \%$ & $7 \%$ & $29 \%$ & $29 \%$ & $31 \%$ & $29 \%$ & $26 \%$ & $12 \%$ \\
\hline$>66$ lat & $14 \%$ & $12 \%$ & $12 \%$ & $7 \%$ & $21 \%$ & $7 \%$ & $12 \%$ & $10 \%$ & $0 \%$ & $7 \%$ & $7 \%$ & $10 \%$ & $7 \%$ & $7 \%$ & $14 \%$ \\
\hline Suma & $67 \%$ & $40 \%$ & $60 \%$ & $47 \%$ & $84 \%$ & $68 \%$ & $60 \%$ & $55 \%$ & $14 \%$ & $57 \%$ & $57 \%$ & $62 \%$ & $55 \%$ & $52 \%$ & $33 \%$ \\
\hline
\end{tabular}

W kolejnym etapie działań ankietowych przeprowadzono analizę wybranych budynków mieszkalnych. Zrealizowano to na przykładzie budynków wybudowanych w technologii prefabrykowanej (system W-70 i OWT-67).

Stwierdzono (Tab. 5), że ogólnie mieszkańcy są zadowoleni z rozkładu pomieszczeń w swoim mieszkaniu (60\%).

A przyczyn migracji, deklarowanej przez mieszkańców, należy dopatrywać się (Tab. 6) w małej powierzchni mieszkań (27\%). Mieszkańcy najchętniej, jeśli mieliby taki wybór i byłoby ich na to stać, migrowaliby z bloku do innej dzielnicy (22\%) lub własnego domu (16\%). Natomiast osoby w wieku >66 lat nie są zainteresowane zamianą mieszkania na inną dzielnicę, ani zmianą budynku na niższy. Mieszkaniem w niższym bloku, co zrozumiałe, nie są też zainteresowane osoby w wieku 18-25 lat. 
Tabela 5. Zestawienie oceny zadowolenia mieszkańców z rozkładu funkcjonalnego pomieszczeń

\begin{tabular}{|c|c|c|}
\hline \multirow{2}{*}{ Wiek } & \multicolumn{2}{|c|}{ Zadowolenie z rozkładu pomieszczeń } \\
\hline $\mathbf{1 8 - 2 5}$ lat & TAK & NIE \\
\hline $\mathbf{2 6 - 4 5}$ lat & $5 \%$ & $5 \%$ \\
\hline $\mathbf{4 6 - 6 5}$ lat & $10 \%$ & $2 \%$ \\
\hline $\mathbf{8 6 \text { lat }}$ & $31 \%$ & $10 \%$ \\
\hline Suma & $14 \%$ & $7 \%$ \\
\hline
\end{tabular}

Tabela 6. Zestawienie przyczyn migracji z budynku zrealizowanym w systemie wielkopłytowym, wg kryterium wieku

\begin{tabular}{|c|c|c|c|c|c|c|}
\hline Wiek & za duże & za małe & niefunkcjonalne & $\begin{array}{c}\text { niższego } \\
\text { bloku }\end{array}$ & innej dzielnicy & własny dom \\
\hline $18-25$ lat & $0 \%$ & $10 \%$ & $0 \%$ & $0 \%$ & $7 \%$ & $2 \%$ \\
\hline 26-45 lat & $2 \%$ & $5 \%$ & $5 \%$ & $10 \%$ & $10 \%$ & $2 \%$ \\
\hline $46-65$ lat & $0 \%$ & $10 \%$ & $2 \%$ & $2 \%$ & $5 \%$ & $7 \%$ \\
\hline$>66$ lat & $0 \%$ & $2 \%$ & $0 \%$ & $0 \%$ & $0 \%$ & $5 \%$ \\
\hline Suma & $2 \%$ & $27 \%$ & $7 \%$ & $12 \%$ & $22 \%$ & $16 \%$ \\
\hline
\end{tabular}

Ogólnie stwierdzono (Tab. 7), że mieszkańcy są zadowoleni z estetyki miejsca zamieszkania (67\%). Poprawę jej dostrzegają w zastosowaniu nowoczesnych elewacji szklanych z systemami odzysku energii i adaptacji ostatniej kondygnacji (po 62\%). Chętnie widzieliby uzupełnienie wyposażenia swojego budynku w windę zabierającą pasażerów z poziomu terenu (36\%) i obudowę balkonów (26\%).

Tabela 7. Zestawienie propozycji poprawy estetyki i wyposażenia budynku - system wielkopłytowy, Lublin, wg kryterium wieku

\begin{tabular}{|c|c|c|c|c|c|c|c|}
\hline$\frac{\text { en }}{3}$ & 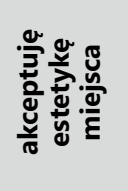 & 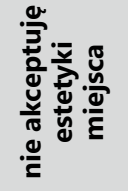 & 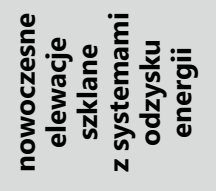 & 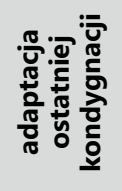 & 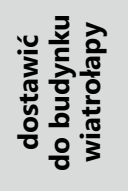 & 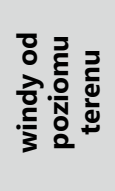 & 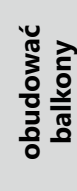 \\
\hline $18-25$ lat & $14 \%$ & $0 \%$ & $14 \%$ & $14 \%$ & $2 \%$ & $10 \%$ & $5 \%$ \\
\hline 26-45 lat & $10 \%$ & $7 \%$ & $12 \%$ & $12 \%$ & $2 \%$ & $0 \%$ & $7 \%$ \\
\hline $46-65$ lat & $26 \%$ & $19 \%$ & $29 \%$ & $29 \%$ & $5 \%$ & $24 \%$ & $12 \%$ \\
\hline$>66$ lat & $17 \%$ & $7 \%$ & $7 \%$ & $7 \%$ & $0 \%$ & $2 \%$ & $2 \%$ \\
\hline Suma & $67 \%$ & $33 \%$ & $62 \%$ & $62 \%$ & $9 \%$ & $36 \%$ & $26 \%$ \\
\hline
\end{tabular}

Poprawę wyposażenia mieszkań lokatorzy upatrują (Tab. 8) we wprowadzeniu: energooszczędnego oświetlenia LED (65\%), czujników ruchu na klatkach schodowych (61\%) oraz w wymianie instalacji elektrycznej w mieszkaniach i zmianie wentylacji grawitacyjnej na wymuszoną z zastosowaniem rekuperatora (55\%), niewiele mniej wymianą instalacji elektrycznej (55\%). Mniej uwagi przywiązują do zmiany funkcji pomieszczeń (13\%). 
Tabela 8. Zestawienie propozycji poprawy wyposażenia mieszkań w systemie wielkopłytowym, Lublin, wg kryterium wieku

\begin{tabular}{|c|c|c|c|c|c|c|c|c|}
\hline 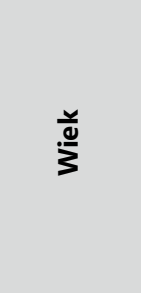 & 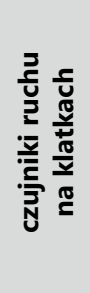 & 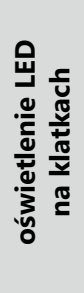 & 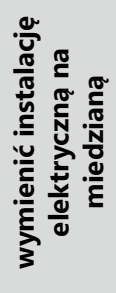 & 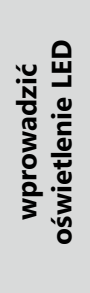 & 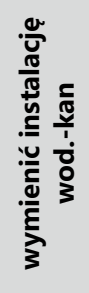 & 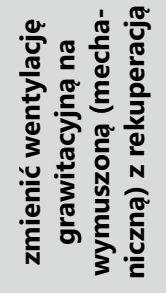 & 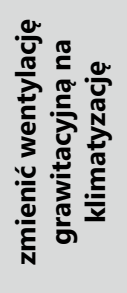 & 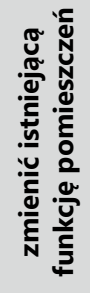 \\
\hline $18-25$ lat & $10 \%$ & $12 \%$ & $10 \%$ & $12 \%$ & $10 \%$ & $10 \%$ & $12 \%$ & $2 \%$ \\
\hline 26-45 lat & $10 \%$ & $5 \%$ & $12 \%$ & $12 \%$ & $10 \%$ & $12 \%$ & $14 \%$ & $2 \%$ \\
\hline 46-65 lat & $29 \%$ & $7 \%$ & $26 \%$ & $31 \%$ & $17 \%$ & $24 \%$ & $21 \%$ & $7 \%$ \\
\hline$>66$ lat & $12 \%$ & $2 \%$ & $7 \%$ & $10 \%$ & $10 \%$ & $10 \%$ & $5 \%$ & $2 \%$ \\
\hline Suma & $61 \%$ & $26 \%$ & $55 \%$ & $65 \%$ & $47 \%$ & $56 \%$ & $52 \%$ & $13 \%$ \\
\hline
\end{tabular}

Mieszańcy wytypowali też działania uzupełniające wyposażenie w sąsiedztwie budynków (Tab. 9), należą do nich: modernizacja placu zabaw (20\%), wykonanie ścianek wspinaczkowych dla młodzieży (19\%), propozycja indywidualnych miejsc parkingowych (15\%), uzupełnienie przestrzeni spacerowej przy budynku ławkami, założenie skateparku i parku linowego (po 14\%) - postulatami tymi są zainteresowane osoby głównie w wieku $18-25$ lat i $46-65$ lat.

Tabela 9. Zestawienie propozycji uzupełnienia wyposażenia w sąsiedztwie, Lublin, wg kryterium wieku

\begin{tabular}{|c|c|c|c|c|c|c|c|c|c|c|c|c|c|c|}
\hline$\stackrel{\frac{0}{3}}{\frac{\pi}{3}}$ & 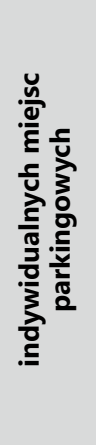 & 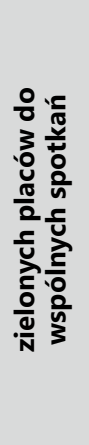 & 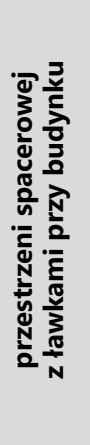 & 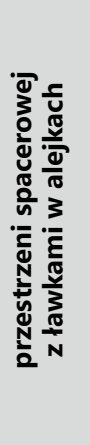 & 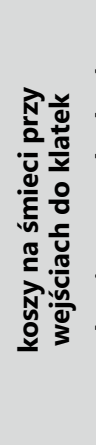 & 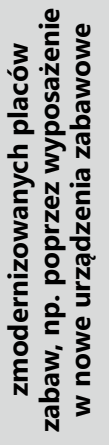 & 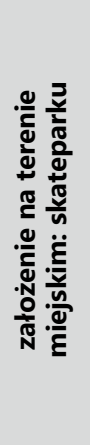 & 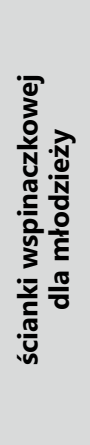 & 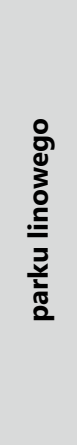 & 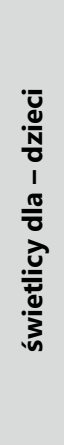 & 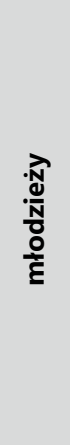 & 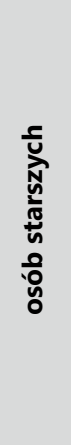 & 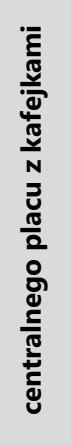 & 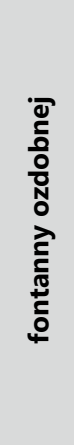 \\
\hline $18-25$ lat & $5 \%$ & $2 \%$ & $2 \%$ & $0 \%$ & $2 \%$ & $5 \%$ & $5 \%$ & $7 \%$ & $5 \%$ & $2 \%$ & $2 \%$ & $2 \%$ & $2 \%$ & $5 \%$ \\
\hline 26-45 lat & $0 \%$ & $0 \%$ & $0 \%$ & $0 \%$ & $5 \%$ & $5 \%$ & $2 \%$ & $2 \%$ & $2 \%$ & $2 \%$ & $2 \%$ & $2 \%$ & $2 \%$ & $0 \%$ \\
\hline 46-65 lat & $10 \%$ & $10 \%$ & $12 \%$ & $7 \%$ & $5 \%$ & $10 \%$ & $7 \%$ & $10 \%$ & $7 \%$ & $2 \%$ & $2 \%$ & $2 \%$ & $5 \%$ & $5 \%$ \\
\hline$>66$ lat & $0 \%$ & $0 \%$ & $0 \%$ & $2 \%$ & $0 \%$ & $0 \%$ & $0 \%$ & $0 \%$ & $0 \%$ & $2 \%$ & $0 \%$ & $0 \%$ & $0 \%$ & $0 \%$ \\
\hline Suma & $15 \%$ & $12 \%$ & $14 \%$ & $9 \%$ & $12 \%$ & $20 \%$ & $14 \%$ & $19 \%$ & $14 \%$ & $8 \%$ & $6 \%$ & $6 \%$ & $9 \%$ & $10 \%$ \\
\hline
\end{tabular}

Natomiast największe oszczędności energetyczne w c.o. i c.w. mieszkańcy widzą (Tab. 10) w montażu OZE, np. solary, panele fotowoltaiczne i pompa ciepła (86\%) oraz wtórnym obiegu wody (71\%), choć nie mają na ten temat zbyt dużej wiedzy. 
Tabela 10. Zestawienie propozycji zmniejszenia zużycia energii cieplnej w skali budynku zrealizowanym w systemie wielkopłytowym, Lublin, wg kryterium wieku

\begin{tabular}{|c|c|c|c|c|c|c|c|c|c|c|c|}
\hline$\stackrel{\text { อั0 }}{3}$ & 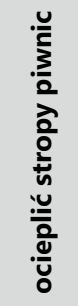 & 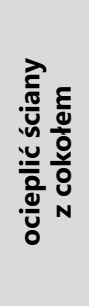 & 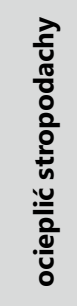 & 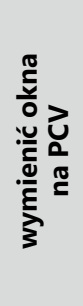 & 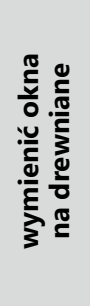 & 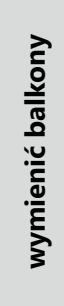 & 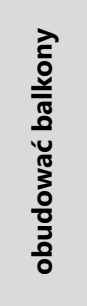 & 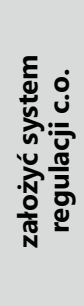 & 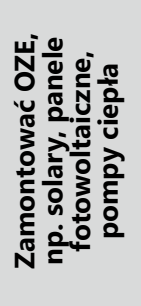 & 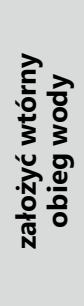 & 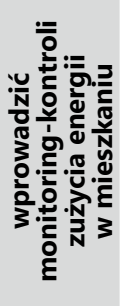 \\
\hline 18-25 lat & $0 \%$ & $0 \%$ & $0 \%$ & $2 \%$ & $5 \%$ & $0 \%$ & $5 \%$ & $7 \%$ & $14 \%$ & $10 \%$ & $7 \%$ \\
\hline 26-45 lat & $10 \%$ & $7 \%$ & $12 \%$ & $10 \%$ & $0 \%$ & $0 \%$ & $10 \%$ & $12 \%$ & $17 \%$ & $14 \%$ & $10 \%$ \\
\hline $46-65$ lat & $19 \%$ & $17 \%$ & $21 \%$ & $24 \%$ & $0 \%$ & $0 \%$ & $5 \%$ & $21 \%$ & $38 \%$ & $33 \%$ & $19 \%$ \\
\hline$>66$ lat & $5 \%$ & $2 \%$ & $2 \%$ & $7 \%$ & $0 \%$ & $2 \%$ & $0 \%$ & $10 \%$ & $17 \%$ & $14 \%$ & $12 \%$ \\
\hline Suma & $34 \%$ & $26 \%$ & $35 \%$ & $43 \%$ & $5 \%$ & $2 \%$ & $20 \%$ & $50 \%$ & $86 \%$ & $71 \%$ & $48 \%$ \\
\hline
\end{tabular}

Efektem badań ankietowych budynków mieszkalnych prefabrykowanych było wytypowanie przez mieszkańców priorytetów prac modernizacyjnych, w których uwzględniono deklarację chęci partycypacji finansowej (Tab. 11).

Jak wykazano, dla lokatorów budynków zrealizowanych w systemie wielkopłytowym najbardziej zauważalne jest malowanie klatek schodowych (53\%), niewiele więcej (50\%) dostawienie windy od poziomu terenu oraz wymiana instalacji elektrycznej (44\%).

Część mieszkańców deklaruje udział w finansowaniu prac konkretnie przez siebie wskazanych (Tab. 11). Badania potwierdziły pobudzenie aktywności mieszkańców co oznacza, że poza opłatami czynszu i ustalonego funduszu remontowego lokatorzy budynków prefabrykowanych deklarują (aż 33\%) dopłatę kwoty 500 zł w skali roku, część zadeklarowała 1000 zł/rok (7\%), a niektórzy nawet 1500 zł/rok (4\%). Kwotę taką mieszkańcy deklarują dołożyć, m.in. do malowania klatek schodowych, dostawienia windy i/lub wymiany instalacji elektrycznej.

Tabela 11. Zestawienie pilnych prac naprawczych, a chęć partycypacji w kosztach - w ramach postawy obywatelskiej - system wielkopłytowy, Lublin, wg kryterium wieku

\begin{tabular}{|c|c|c|c|c|c|c|c|c|c|c|c|c|c|c|}
\hline 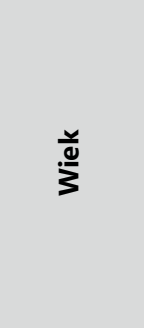 & 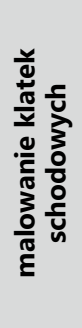 & 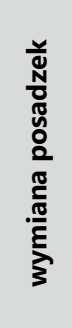 & 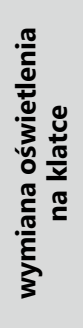 & $\begin{array}{l}\frac{\lambda}{0} \\
\cdot \frac{5}{3} \\
.0 \\
\frac{0}{2} \\
\cdot \frac{0}{3} \\
\frac{\pi}{\hbar} \\
\frac{0}{0}\end{array}$ & 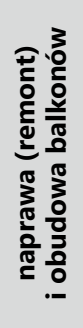 & 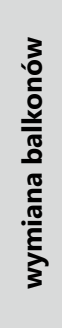 & 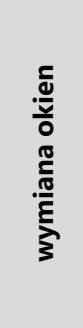 & 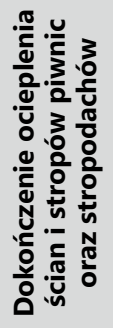 & 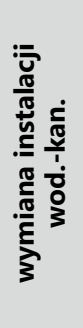 & 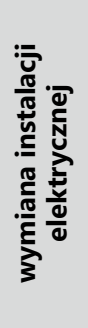 & 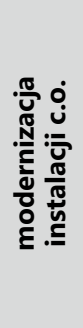 & $\begin{array}{l}\frac{y}{0} \\
\frac{1}{N} \\
\text { N } \\
\text { ○ }\end{array}$ & $\begin{array}{l}\text { 은 } \\
\frac{N}{N} \\
8 \\
8\end{array}$ & 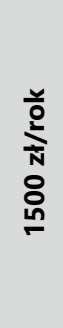 \\
\hline $18-25$ lat & $10 \%$ & $0 \%$ & $0 \%$ & $7 \%$ & $2 \%$ & $2 \%$ & $7 \%$ & $0 \%$ & $7 \%$ & $10 \%$ & $7 \%$ & $5 \%$ & $0 \%$ & $0 \%$ \\
\hline 26-45 lat & $5 \%$ & $2 \%$ & $5 \%$ & $5 \%$ & $0 \%$ & $0 \%$ & $2 \%$ & $5 \%$ & $7 \%$ & $10 \%$ & $0 \%$ & $7 \%$ & $2 \%$ & $2 \%$ \\
\hline $46-65$ lat & $26 \%$ & $5 \%$ & $10 \%$ & $36 \%$ & $5 \%$ & $0 \%$ & $12 \%$ & $5 \%$ & $7 \%$ & $17 \%$ & $5 \%$ & $14 \%$ & $5 \%$ & $2 \%$ \\
\hline$>66$ lat & $12 \%$ & $7 \%$ & $2 \%$ & $2 \%$ & $0 \%$ & $0 \%$ & $2 \%$ & $0 \%$ & $7 \%$ & $7 \%$ & $2 \%$ & $7 \%$ & $0 \%$ & $0 \%$ \\
\hline Suma & $53 \%$ & $14 \%$ & $17 \%$ & $50 \%$ & $7 \%$ & $2 \%$ & $23 \%$ & $10 \%$ & $28 \%$ & $44 \%$ & $14 \%$ & $33 \%$ & $7 \%$ & $4 \%$ \\
\hline
\end{tabular}




\section{Podsumowanie}

Wyniki analizy statystycznej potwierdzają tendencje do starzenia i tym samym ubożenia społeczeństwa w Lublinie.

Analiza wyników badań inwentaryzacji stanu funkcjonalnego i energetycznego wybranego obszaru badawczego, uwzględniającego niskie budynki wielorodzinne z lat 70. i 80., pozwoliła uzyskać wiedzę na temat problemów funkcjonalnych i energetycznych, dotychczas nieusuniętych lub powstałych w ostatnim czasie w analizowanych budynkach.

Istotnym dla zarządców wydaje się być to, że ponad 60\% mieszkańców akceptuje swoje środowisko zamieszkania i chce pozostać w swoich mieszkaniach. A dodatkowo część mieszkańców wyraża nawet zainteresowanie i chęć współpracy w partycypacji do planowanych działań.

Dzięki przeprowadzonej analizie badań określono zakres zarówno zakres i kolejność działań w uzgodnieniu z mieszkańcami, ale również możliwość uwzględnienia ich w partycypacji. Lokatorzy zauważają, niekiedy bardziej niż zarządcy, potrzebę uzupełnienia wyposażenia budynków i wymiany zużytych instalacji (blisko 50\%). Jeszcze więcej widzi możliwość dalszych oszczędności energetycznych w odnawialnych źródłach energii (OZE) i ekologii (wtórny obieg wody w łazienkach lub wykorzystanie wody deszczowej).

Na podstawie analizy wyników badań stwierdzono, że nadal istnieje możliwość poprawy funkcjonalnej i zwiększenia efektywności energetycznej w przypadku zastosowania przynajmniej części z zaproponowanych działań. Wymaga to jednak synergicznego sposobu zarządzania i indywidualnego podejścia, w każdym typie budynków, wynikającego z przeprowadzonych analiz opartych, m.in. na dotychczasowym stanie i kalkulacji opłacalności inwestycji.

Rozpoznanie potrzeb osiedli i uaktualnienie potrzeb mieszkańców za pomocą ankiet społecznych może być przyczynkiem do opracowania zarówno programu rewitalizacji prowadzącego do zrównoważonego rozwoju, np. wg kryteriów i poziomów odpowiedzialności [9], jako dziedzictwo przyszłych pokoleń, ale również do wypracowania możliwego do realizacji programu poprawy funkcjonalnej oraz energooszczędnego i ekologicznego podejścia dla różnego rodzaju budynków (nie tylko mieszkalnych).

Na podstawie badań społecznych przeprowadzonych w Lublinie wydaje się być uzasadnione stwierdzenie, że zaproponowana metodologia i uzyskane analizy wyników lubelskich badań mogą być aplikowane na terenie całej Polski.

\section{Bibliografia}

[1] Gruszczyński L.A., Kwestionariusze w socjologii. Budowa narzędzi do badań surveyowych. Wydawnictwo Uniwersytetu Śląskiego, Katowice 2001, s. 33-34.

[2] http://swaid.stat.gov.pl/Demografia_dashboards/Raporty_predefiniowane/RAP_DBD_DEM_18.aspx. 2021.03.20.

[3] https://bip.stat.gov.pl > urzad-statystyczny-w-lublinie, dostęp 20.03.2021.

[4] Ostańska A., Badania wybranych obszarów w Lublinie z uwzględnieniem typoszeregów budynków. Teka Komisji Architektury, Urbanistyki i Studiów Krajobrazowych - Polska Akademia Nauk. Oddział w Lublinie, 2020, vol. 16, nr 3, s. 58-65.

[5] Ostańska A., Podstawy metodologii tworzenia programów rewitalizacji dużych osiedli mieszkaniowych wzniesionych w technologii uprzemysłowionej na przykładzie osiedla im. St. Moniuszki w Lublinie, Politechnika Lubelska, Monografie Wydziału Inżynierii Budowlanej i Sanitarnej Vol. 1, Wydawnictwa Uczelniane, Lublin 2009, ss. 1-173.

[6] Ostańska A., Programowanie rewitalizacji osiedli mieszkaniowych z zastosowaniem modelu PEARS. Lublin: Polska Akademia Nauk, 2018. 169 s. ISBN 978-83-939534-4-8.

[7] Sztumski J., Wstęp do metod i technik badań społecznych. Uniwersytet Śląski Zeszyt 136. Katowice 1976 i późniejsze (do 2001), ss. 38-39 i 98-99.

[8] Urząd Miasta Lublin Wydział Strategii i Przedsiębiorczości www.strategia.lublin.eu.

[9] Zaniewska H., Kowalewski A.T., Thiel M., Barek R., Zrównoważony rozwój osiedli i zespołów mieszkaniowych w strukturze miasta. Kryteria i poziomy odpowiedzialności, Kraków 2008. 


\section{Proposal for synergic management and energy saving in a housing estate based on residents' opinion - example of Lublin}

Abstract: As part of the proposal for synergic management of the housing estate, the multifaceted opinions expressed by the users of the multifamily buildings that have been in use for many years were analysed in a face-to-face interview. The result of the analysis was to identify the aspects most frequently supported by the residents and to indicate further directions for possible and acceptable actions. Then, a selection was made of the most urgent actions indicated by the inhabitants in terms of energy saving, which, synchronised with the financial possibilities of the manager, could contribute to a coherent design of future corrective actions and their smooth implementation.

Keywords: dwelling, multifamily building in operation, housing estate, energy saving, users' opinion. 